\title{
Effect of Different Levels of Fertigation on Flowering and Storage Life of Marigold (Tagetes erecta L.) CV. Pusa Narangi Gainda
}

\author{
Kurakula Divya*, A. Girwani ${ }^{1}$, D. Vijaya ${ }^{2}$ and P. Prasanth ${ }^{3}$ \\ ${ }^{1}$ College of Horticulture, Mojerla, India \\ ${ }^{2}$ Soil Science, Grape Research Station, Rajendranagar, India \\ ${ }^{3}$ Floricultural Research Station, Rajendranagar, India \\ *Corresponding author
}

A B S T R A C T

\begin{tabular}{|l|}
\hline Ke y w o r d s \\
Marigold, \\
$\begin{array}{l}\text { Fertigation, Water } \\
\text { soluble fertilizers, } \\
\text { Flower parameters, } \\
\text { Shelf life }\end{array}$ \\
\hline Article Info \\
\hline $\begin{array}{l}\text { Accepted: } \\
\text { 07 November } 2018 \\
\text { Available Online: } \\
\text { 10 December } 2018\end{array}$ \\
\hline
\end{tabular}

\section{Introduction}

In India, various traditional flowers have been growing since time immemorial, among those, marigold has a unique status. Marigold is one of the easiest grown annual flowers and has wide adaptability to different soil and climatic conditions. The plants with their attractive flower colour and long blooming period remain fresh for quite a long time after plucking. All these factors have made marigold as one of the most popular annual flowers in India, for garden display as well as for commercial cultivation.
An experiment was conducted to study the effect of levels of fertigation on flowering and shelf life of marigold (Tagetes erecta L.) cv. Pusa Narangi Gainda under open conditions at Floricultural Research Station, Rajendranagar, Hyderabad during 2016-2017. The experiment consisted of seven levels of fertigation treatments with combination of water soluble and straight fertilizers. The results revealed that flowering and storage life of marigold flowers were significantly influenced by different levels of fertigation. Duration of flowering (45.74 days), number of pickings per month (5.10), flower yield per plot $(23.37 \mathrm{~kg} / \mathrm{plot})$ and flower yield per hectare (14.42 t/ha) were maximum with the application of 75 per cent of recommended dose of fertilizers (RDF) with Water Soluble fertilizers. Further at the same fertigation level shelf life of flowers (3.59 days) and shelf life of flowers packed in polyethylene cover (5.25 days) were recorded maximum. 
cultivation by reducing the cost of water, fertilizers, labour and energy (Khan et al., 1997). Inadequate plant nutrition causes serious nutritional disorders in marigold cultivation and may eventually lead to decline of plant vigour and ultimately reduction of yield.

Hence, for successful cultivation of marigold optimum level of fertilizer dosages through fertigation need to be worked out in improving the fertilizer use efficiency and reducing the cost of cultivation. In view of above facts the present work has been taken up to study the influence of different levels of fertigation and sources of nutrients in marigold cv. Pusa Narangi gainda.

\section{Materials and Methods}

The experiment was conducted during the year $2016-17$ to study the effect of levels of fertigation on flowering and storage life of marigold grown under open conditions at Floricultural Research Station, Rajendranagar, Hyderabad. The experiment site was red sandy loam soil with a $\mathrm{pH}$ of 7.38 and EC 0.33. The experiment was laid out in Randomized Block Design (RBD) comprising seven treatments with three replications and RDF of 90:90:75 $\mathrm{kg}$ NPK ha ${ }^{-1}$. The treatments consists of $\mathrm{T}_{1}$ : $75 \%$ of RDF with Water soluble fertilizers (WSF), $\mathrm{T}_{2}: 100 \%$ of RDF with WSF, $\mathrm{T}_{3}$ : $125 \%$ of RDF with WSF, $\mathrm{T}_{4}: 75 \%$ of RDF as $\mathrm{WSF}+25 \%$ of RDF as straight fertilizers (SF), $\mathrm{T}_{5}: 50 \%$ of RDF as WSF $+50 \%$ of RDF as $\mathrm{SF}, \mathrm{T}_{6}: 25 \%$ of $\mathrm{RDF}$ as $\mathrm{WSF}+75 \%$ of RDF as SF, $\mathrm{T}_{7}: 100 \%$ of RDF as SF (control). At last ploughing 20 tonnes of Farm yard manure and 422 kilo grams of Single super phosphate (75\% RDF) were applied as basal, along with this each 2 kilo grams of Azospirillum, 2.5 kilograms of Pseudomonas fluorescens and Phospho bacteria were mixed with $50 \mathrm{~kg}$ of FYM per hectare and were applied uniformly for all the treatments.
The drip irrigation system and venturi injector fertigation unit were installed as per the experimental layout and treatment plan. Twenty five days old healthy and uniform seedlings of cv. Pusa Narangi gainda were transplanted in the main field in double row system of planting at four leaf stage with a spacing of $60 \mathrm{~cm}$ between the rows and $30 \mathrm{~cm}$ between the plants. Water soluble fertilizers and straight fertilizers were applied as per the treatment combinations. Fertigation was given twice a week as per the plant growth stage. Observations were recorded on flower parameters and storage life of marigold flowers in different treatments. The data collected were subjected to statistical analysis as per Panse and Sukhatme (1978).

\section{Results and Discussion}

The data pertaining to the flowering and storage life of marigold cv. Pusa Narangi Gainda are presented in tables 1 and 2 respectively.

The application of different levels of fertigation in water soluble and straight fertilizers differed non-significantly in plant spread during initial stages of plant growth (in both directions E-W and N-S). This might be due to various levels of fertigation had no significant influence on growth and development at early stages of plant growth. On contrary, Palanisamy et al., (2015) in gerbera and Vasudevan et al., (2014) in rose reported significant differences in plant spread under different fertigation levels.

The results indicated that there was no significant difference in stem girth of marigold under different levels of fertigation at first flower bud appearance stage. This concurs with the results of a study conducted by Henny (1999) who observed non significant difference at initial stages in anthurium plants. 
The results revealed that the fertigation at various concentrations had significant influence on flowering duration of marigold. The duration of flowering in marigold was enhanced with the application of 75 per cent of RDF using WSF and recorded the maximum flowering duration of 45.74 days and minimum duration of flowering (33.68days) was recorded with 125 per cent of RDF using WSF. This might be due to nutrient levels that are above optimum level did not improve the plant growth and in addition excessive nutrients can cause adverse effects on plant growth (Manian et al., 2006). This result supports earlier findings of Vijay Kumar et al., (2010) and Thamara et al., (2010) in china aster who reported earlier significant difference in duration of flowering with different levels of fertigation.

The analysis of the data showed that statistically there was significant influence on number of flower pickings month $^{-1}$ of marigold cv. Pusa Narangi Gainda. The maximum flower pickings month ${ }^{-1}(5.10)$ was recorded with the application of 75 per cent of RDF as WSF followed by 25 per cent of RDF as WSF + 75 per cent of RDF as SF (5.06). This attributes might be due to continuous and optimal supply of nutrients increases nutrient uptake of plant resulted in better growth in terms of number of branches, increased number of flowers which in general have significant positive correlation with number of pickings. The results of the present study are in conformity with Thumar et al., (2013), Kapadiya et al., (2007) and Naik et al., (2008) in marigold.

Significant difference was recorded among treatments on flower yield plot $^{-1}$ and flower yield $\mathrm{ha}^{-1}$ of marigold. The maximum flower yield $\operatorname{plot}^{-1}(23.37 \mathrm{~kg})$ and flower yield $\mathrm{ha}^{-1}$ $(14.42 \mathrm{t})$ were obtained with 75 per cent of RDF with WSF might be due to the continuous supply of optimum dose of water soluble fertilizers in available form through fertigation at critical stages of plant growth leads to higher uptake and better translocation of assimilates from source to sink which in turn increased the yield. This finding is in accordance with the findings of Gopinath and Chandra Shekar (2009) in carnation and Shrikant et al., (2014) in gerbera.

Increase of shelf life of marigold flowers enables the storage of flowers for a length of time during the surplus production in the market and is also feasible for the long distance transportation. Application of 75 per cent of RDF using WSF was recorded significantly maximum shelf life of flowers (3.59 days) while the minimum shelf life of flowers (2.50 days) was recorded $\left(\mathrm{T}_{2}\right)$ in 100 per cent of RDF using WSF in room conditions. The increase in level of fertigation decreased the shelf life of flowers in marigold. According to Anuradha et al., (1990) this results might be due to higher dose of nitrogen keeps the flower soft and succulent in texture which resulted in higher and faster respiration and dehydration. Similar observations were earlier reported by Ganesh et al., (2014) in chrysanthemum and Vijay kumar et al., (2010) in China aster.

In ambient room conditions, shelf life of marigold flower in polyethylene cover was increased significantly with various concentrations of fertigation. The flowers from the treatment 75 per cent of RDF using WSF recorded maximum shelf life of PE packed flowers (5.25 days) and it was on par with the treatment 25 per cent of RDF as WSF + 75 per cent of RDF as SF (4.83 days). Maintenance of maximum freshness in flowers in this case might be due to higher levels of moisture content. Due to maintenance of appreciable levels of moisture, the enzymes peroxidase and catalase remained highly active thus delaying the aging of flowers (Tanner et al., 2001) (Fig. 1 and 2). 
Table.1 Effect of levels of fertigation on growth and flowering characters of marigold cv. Pusa Narangi Gainda

\begin{tabular}{|c|c|c|c|c|c|}
\hline \multirow[t]{2}{*}{ Treatments } & \multicolumn{2}{|c|}{ Plant spread (cm) } & \multirow{2}{*}{$\begin{array}{l}\text { Stem girth } \\
(\mathrm{mm})\end{array}$} & \multirow{2}{*}{$\begin{array}{c}\text { Flowering duration } \\
\text { (day) }\end{array}$} & \multirow{2}{*}{$\begin{array}{l}\text { No. of pickings } \\
\text { per month }\end{array}$} \\
\hline & $(\mathrm{E}-\mathrm{W})$ & $(\mathbf{N}-\mathbf{S})$ & & & \\
\hline $\mathrm{T}_{1}: 75 \%$ of RDF using WSF & 41.00 & 11.52 & 8.41 & 45.74 & 5.10 \\
\hline $\mathrm{T}_{2}: 100 \%$ of RDF using WSF & 36.27 & 9.97 & 7.55 & 34.20 & 4.37 \\
\hline $\mathrm{T}_{3}: 125 \%$ of RDF using WSF & 36.82 & 10.62 & 7.49 & 33.68 & 4.31 \\
\hline $\mathrm{T}_{4}: 75 \%$ of RDF as WSF $+25 \%$ of RDF as SF & 37.13 & 10.32 & 7.81 & 34.67 & 4.37 \\
\hline $\mathrm{T}_{5}: 50 \%$ of RDF as WSF $+50 \%$ of RDF as SF & 39.90 & 10.65 & 7.53 & 34.50 & 4.35 \\
\hline $\mathrm{T}_{6}: 25 \%$ of RDF as WSF $+75 \%$ of RDF as SF & 38.10 & 11.21 & 8.27 & 44.50 & 5.06 \\
\hline $\mathrm{T}_{7}: 100 \%$ straight fertilizers (Control) & 37.43 & 10.60 & 8.08 & 43.82 & 4.93 \\
\hline S.Em \pm & 1.57 & 0.46 & 0.07 & 0.84 & 0.02 \\
\hline $\mathrm{CD}(\mathrm{P}=0.05)$ & N.S. & N.S. & 0.21 & 2.61 & 0.06 \\
\hline
\end{tabular}

RDF- Recommended Dose of Fertilizers, SF- Straight Fertilizers, WSF- Water soluble fertilizers RDF - 90:90:75 kg NPK ha ${ }^{-1}$

Table.2 Influence of levels of fertigation on flower yield and shelf life of marigold cv. Pusa Narangi Gainda

\begin{tabular}{|c|c|c|c|c|}
\hline Treatments & $\begin{array}{l}\text { Flower yield } \\
\left(\mathrm{kg} \mathrm{plot}^{-1}\right)\end{array}$ & $\begin{array}{l}\text { Flower yield } \\
\qquad\left(\mathrm{t} \mathrm{ha}^{-1}\right)\end{array}$ & $\begin{array}{l}\text { Shelf life of loose } \\
\text { flowers (day) }\end{array}$ & $\begin{array}{l}\text { Shelf life of flowers } \\
\text { in PE cover (day) }\end{array}$ \\
\hline$T_{1}: 75 \%$ of RDF using WSF & 23.37 & 14.42 & 3.59 & 5.25 \\
\hline $\mathrm{T}_{2}: 100 \%$ of RDF using WSF & 20.74 & 12.80 & 2.50 & 4.02 \\
\hline $\mathrm{T}_{3}: 125 \%$ of RDF using WSF & 19.37 & 11.96 & 2.51 & 4.20 \\
\hline $\mathrm{T}_{4}: \mathbf{7 5} \%$ of RDF as WSF $+25 \%$ of RDF as SF & 20.63 & 12.73 & 2.72 & 4.07 \\
\hline $\mathrm{T}_{5}: 50 \%$ of RDF as WSF $+50 \%$ of RDF as SF & 20.69 & 12.77 & 2.56 & 4.01 \\
\hline $\mathrm{T}_{6}: 25 \%$ of RDF as WSF $+75 \%$ of RDF as SF & 22.84 & 14.28 & 3.36 & 4.83 \\
\hline $\mathrm{T}_{7:} \mathbf{1 0 0 \%}$ straight fertilizers (Control) & 22.82 & 14.23 & 3.11 & 4.35 \\
\hline S.Em \pm & 0.25 & 0.07 & 0.07 & 0.19 \\
\hline $\mathrm{CD}(\mathrm{P}=0.05)$ & 0.78 & 0.20 & 0.21 & 0.59 \\
\hline
\end{tabular}

RDF- Recommended Dose of Fertilizers, SF- Straight Fertilizers, WSF- Water soluble fertilizers, PE- Polyethylene

RDF - 90:90:75 kg NPK ha ${ }^{-1}$ 
Fig.1 Effect of different levels of fertigation on shelf life of marigold flower (day) at ambient room conditions

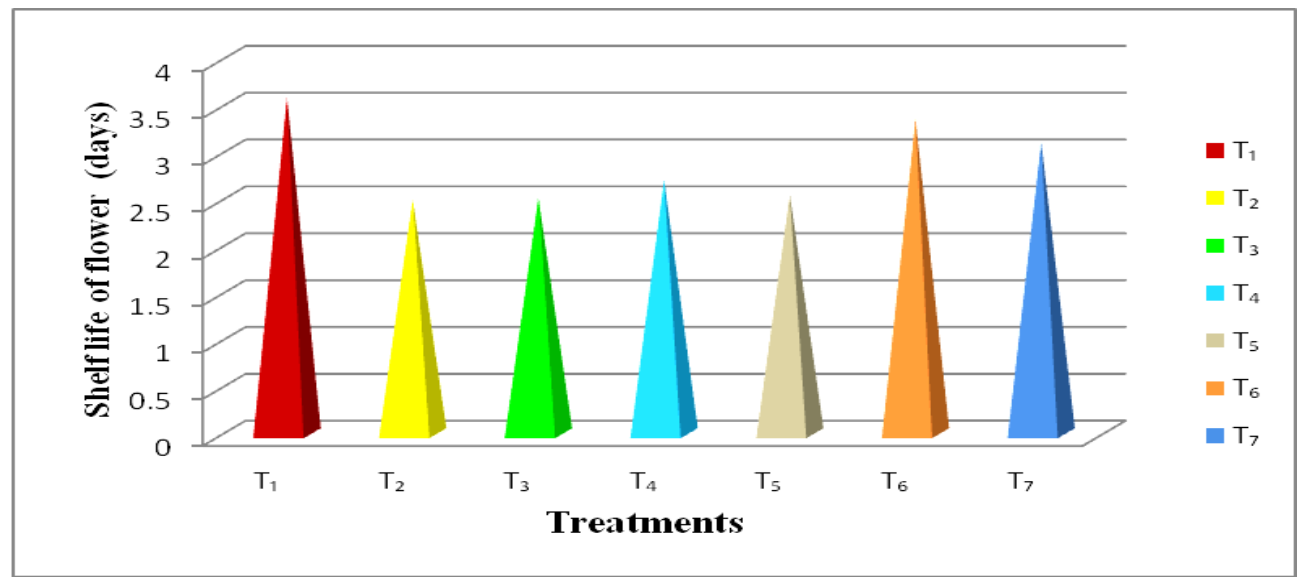

Fig.2 Effect of different levels of fertigation on shelf life of marigold flower packed in polyethylene cover at ambient room conditions (day)

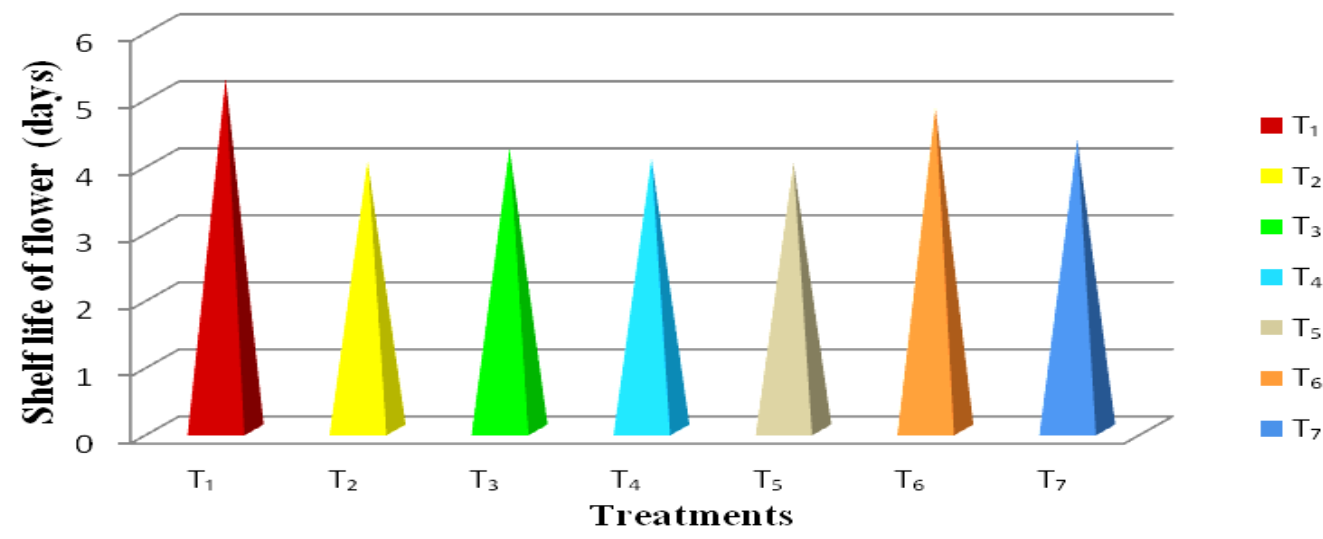

$* \mathbf{T}_{\mathbf{1}}-75 \%$ of RDF using WSF, $\mathbf{T}_{\mathbf{2}}-100 \%$ of RDF using WSF, $\mathbf{T}_{\mathbf{3}}-125 \%$ of RDF using WSF, $\mathbf{T}_{\mathbf{4}}-75 \%$ of RDF as WSF $+25 \%$ of RDF as SF, $\mathbf{T}_{\mathbf{5}}-50 \%$ of RDF as WSF $+50 \%$ of RDF as SF, $\mathbf{T}_{\mathbf{6}}-25 \%$ of RDF as WSF $+75 \%$ of RDF as SF, $\mathbf{T}_{7}-100 \%$ of $\mathrm{RDF}$ as SF (control).

From the results of the present investigation, it can be inferred that the fertigation with 75 per cent of recommended dose of fertilizers with water soluble fertilizers proved to be most optimal dose for increasing yield and shelf life of marigold flowers grown during rabi season under Telangana conditions.

\section{References}

Anuradha, K, Pampapathy, K and Narayana, N. 1990. Effect of nitrogen and phosphorus on flowering, yield and quality of marigold. Indian J. Hort. 47(3): 357-363.

Ganesh, S, Kannan, $\mathrm{M}$ and Jawaharlal, $\mathrm{M}$. 2014. Optimization of fertigation schedule for cut chrysanthemum (Dendranthema grandiflora Tzvelev). Hort Flora Research Spectrum. 3(4): 344348.

Gopinath, G and Chandrashekar, S. Y. 2009. Yield of carnation as influenced by levels of fertigation and sources of nutrients of growing standard carnation cv. Trendy 
under cost greenhouse. Journal of Ornamental Horticulture. 12(4): 251-255.

Henny, R. J. 1999. Red Hot anthurium. Hort. Sci. 34(1): 153-155.

Kapadiya, D. B. 2007. Effect of bio inoculants on growth and yield of African marigold (Tagetes erecta L.) Cv. Pusa Narangi Gainda. M.Sc. (Ag.) Thesis, Navsari Agricultural University. Navsari. Gujarat (India).

Khan, M. M, Shyamalamma, S and Krishna manohar, R. 1997. Relevance of green house technology in India. In: Progressive floriculture. The house of Sarpan, Bangalore, pp:1-6.

Manian, K, Chandrasekhar, C. N and Vijayakumar, M. 2006. Advances in ornamental horticulture. Pointer publishers, Jaipur. 182-185.

Naik, B. H, Shubha, B. M, Patil, B. C, Patil, A. A and Chandra shekar, S. Y. 2008. Effect of integrated nutrient management for carotenoid yield in African marigold. Nat. symp. on recent advances in floriculture. Navsari. pp.54.

Palanisamy, Kannan, D, Sharma, R, Siddharth, S. B and Abhay Singh, 2015. Fertigation studies on gerbera (Gerbera jamesonii bolus ex hooker F.) for growth and yield under cover in southern hills (Shevaroy). National academy of agricultural science. 33(1): 31-36.

Panse, V. G and Sukhatme P. V. 1978. Statistical methods for agricultural workers. Indian Council of Agricultural Research, New Delhi. 1-317.

Papadopoulos, I. 1992. Phosphate fertigation of trickle- irrigated potato. Fertil Res. 31: 913.

Shrikant, M and Jawaharlal, M. 2014. Effect of fertigation level and biostimulants on quality parameters of Gerbera var. Debora under polyhouse conditions. Trends in Bio sciences. 7(11): 1134-1137.

Tanner, D. J, Cleland, A. C, Opara, L. U. and Robertson, T. R. 2001. A generalised mathematical modelling methodology for designing of horticultural food packages exposed to refrigerate conditions: Part 1, formulation. International Journal Refrigeration. 25: 33-42.

Thamara, M. P, Kumar, D. P, Ratnayake, U. A. J, Jayaprasad, K. V and Krishna manohar, R. 2010. Effect of fertigation on flower yield and quality of china aster Callistephus chinensis (L.) Nees under open condition. Mysore J. Agi. Sci. 44 (1): 39-43.

Thumar, B. V, Barad, A. V, Neelima, P and Nilima, B. 2013. Effect of integrated system of plant nutrition management on growth, yield and flower quality of African marigold (Tagetes erecta L.) Cv. Pusa Narangi. Asian Journal of Horticulture. 8(2): 466-469.

Vasudevan, V and Kannan, M. 2014. Effect of fertigation, micronutrients and Bacillus sp for maximizing the yield, quality and disease management of rose (Rosa hybrida var. Tajmahal) under greenhouse conditions. Trends in Biosciences. 7(13).

Vijaykumar, N. S, Gopinath, G and Krishna manohar, R. 2010. Growth, flowering and post harvest life of China aster as influenced by drip irrigation and fertigation. Mysore J. Agri. Sci. 44 (2): 326-331.

\section{How to cite this article:}

Kurakula Divya, A. Girwani, D. Vijaya and Prasanth, P. 2018. Effect of Different Levels of Fertigation on Flowering and Storage Life of Marigold (Tagetes erecta L.) CV. Pusa Narangi Gainda. Int.J.Curr.Microbiol.App.Sci. 7(12): 521-526. doi: https://doi.org/10.20546/ijcmas.2018.712.065 